\title{
Rethinking Judicial Narratives: The Court of Justice and the Treaty of Rome
}

\author{
Thomas Horsley*
}

William Phelan, Great Judgments of the European Court of Justice: Rethinking the Landmark Decisions of the Foundational Period (Cambridge University Press 2019) pp. 258.

\section{INTRODUCTION}

In Great Judgments of the European Court of Justice, William Phelan invites readers to rethink a selection of the Court of Justice's formative cases addressing the foundations of the (then) Community legal order. Most of these decisions, such as Van Gend en Loos ${ }^{1}$ and Costa $\vee E N E L^{2}$ are well-known to European legal scholars; others, notably Pork Products, ${ }^{3}$ Dairy Products ${ }^{4}$ and Sheep Meat, ${ }^{5}$ perhaps less so. Great Judgments set its sights on challenging the received account of these decisions as the basis of a 'new legal order' in which, atypically among international treaty organisations, private litigants and national courts have acquired direct and powerful roles. ${ }^{6}$ Asserting that leading scholars have 'missed the bigger picture'

*Senior Lecturer, University of Liverpool; Email: Thomas.Horsley@liverpool.ac.uk. I am grateful to the editors for their comments on an earlier draft.

${ }^{1}$ ECJ 5 February 1963, Case 26/62, Van Gend en Loos ECLI:EU:C:1963:1.

${ }^{2}$ ECJ 15 July 1964, Case 6/64, Costa v ENEL ECLI:EU:C:1964:66.

${ }^{3}$ ECJ 19 December 1961, Case 7/61, Commission v Italy ECLI:EU:C:1968:51.

${ }^{4}$ ECJ 13 November 1964, Joined Cases 90/63 and 91/63, Commission v Luxembourg and Belgium ECLI:EU:C:1964:80.

${ }^{5}$ ECJ 25 September 1979, Case 232/78, Commission v France ECLI:EU:C:1979:215.

${ }^{6}$ See e.g., J.H.H Weiler, 'The Transformation of Europe', 100 Yale Law Journal (1991) p. 2403 and K. Alter, Establishing the Supremacy of European Law (Oxford University Press 2001). See also B. de Witte, 'Direct Effect, Primacy and the Nature of the Legal Order', in P. Craig and G. de Búrca (eds.), The Evolution of EU Law (Oxford University Press 2011).

European Constitutional Law Review, 17: 553-565, 2021

(C) The Author(s), 2021. Published by Cambridge University Press on behalf of European Constitutional Law Review. This is an Open Access article, distributed under the terms of the Creative Commons Attribution licence (https://creativecommons.org/licenses/by/4.0/), which permits unrestricted re-use, distribution, and reproduction in any medium, provided the original work is properly cited. doi:10.1017/S1574019621000298 
(p. 228), ${ }^{7}$ Phelan weaves together an alternative historical narrative that displaces talk of individual (and national court) empowerment. ${ }^{8}$ According to Phelan, the Court's early case law is better understood as a necessary intervention to manage inter-state trade disputes arising through the operation of the Treaty of Rome as an international treaty (p. 3).

But Great Judgments attempts to do more than rethink entrenched scholarly perspectives on some of the Court's most famous early decisions. It goes further, defending a second, more ambitious claim. Looking beyond the text of individual judgments, Phelan argues that we may largely attribute the Court's approach to resolving practical problems of inter-state trade relations to one individual: the French lawyer and President of the Court of Justice (1967-1976), Robert Lecourt. Bold claims accompany Lecourt's featuring on the front cover of this new book. Phelan asserts that, 'no other single judge has had such a profound influence on the development of European law' (p. 5). In particular, it is Lecourt, we are told, whom we must credit for pioneering the revisionist account of the Court's jurisprudence on direct effect and primacy that underpins Great Judgments.

In attempting to rethink established narratives, whilst simultaneously exploring the writings of influential legal figures, Great Judgments is at the vanguard of contemporary studies of the Court of Justice and the EU legal order more broadly. Recent years have witnessed a renewal of interest among lawyers, political scientists and legal historians in the Court, including its early workings. ${ }^{9}$ Like Phelan's book, much of this work responds to that powerful intellectual urge periodically to revisit apparently settled narratives. In contrast to Great Judgments, however, strands of this emerging body of research are also more critical in places, introducing discomfort into dominant accounts of progressive post-War liberal

\footnotetext{
${ }^{7}$ At points, Phelan is rather forthright in his criticism of existing perspectives, writing of 'persistent neglect' (p. 222) and 'intellectual flaws' (p. 223).

${ }^{8}$ See e.g. Alter, supra n. 6.

${ }^{9}$ E.g., M. Rasmussen, 'The Origins of a Legal Revolution: The Early History of the European Court of Justice', 14(2) Journal of European Integration History (2008) p. 7; B. Davies, Resisting the European Court of Justice: West Germany's Confrontation with European Law, 1949-1979 (Cambridge University Press 2012); A. Vauchez, Brokering Europe: Euro-Lawyers and the Making of a Transnational Polity (Cambridge University Press 2015); D. Sindbjerg Martinsen, An Ever More Powerful Court? The Political Constraints of Legal Integration in the European Union (Oxford University Press 2015); D. Grimm, The Constitution of European Democracy (Oxford University Press 2017); T. Horsley, The Court of Justice of the European Union as an Institutional Actor: Judicial Policymaking and its Limits (Cambridge University Press 2018); S.K. Schmidt, The European Court of Justice and the Policy Process: The Shadow of Case Law (Oxford University Press 2018); and C. Kilpatrick and J. Scott (eds.), New Legal Approaches to Studying the Court of Justice: Revisiting Law in Context (Oxford University Press 2020).
} 
European politics. ${ }^{10}$ The new wave is yet to break, and we may look forward to further intellectual contributions. For legal historians, in particular, the Luxembourg Court's decision to provide public access to its archives through the Historical Archives of the European Union (European University Institute) will, no doubt, provide a rich new source of data for future research. ${ }^{11}$

But Great Judgments is not a work of legal history. Nor is it, methodologically, a particularly robust example of comparative legal research (Great Judgments is framed as a comparative study). ${ }^{12}$ It remains principally a doctrinal legal analysis of the Court of Justice's case law. As illuminating as they are, the historical and comparative dimensions of Phelan's book essentially provide a deeper and enriching context to support the core argument. The question, of course, is whether this fusion of doctrinal analysis and deeper context succeeds in its ambition to make us 'rethink' our understanding of the Court of Justice's early case law on direct effect and primacy? And, to the extent that it does, we may also legitimately ask what added value follows in result? Legal scholars ought to do more than scratch itches.

\section{A CONCEPTUAL TURN}

An immediately striking feature of Great Judgments is its pivot to international law to provide a conceptual framework to revise our understanding of the Court of Justice's early case law, especially on direct effect and primacy. Phelan does not make too much of this move. But it is as bold and refreshing as the narrative he seeks to defend. The very idea that the European legal system should be viewed through the prism of international law - something I have explored in my own work $^{13}$ - remains largely anathema to most EU legal scholars. As Plender noted,

no principle of Community law is more fundamental, no more frequently reiterated by the European Court, than that the Treaty establishing the European Economic Community is 'more than an agreement which merely creates obligations between contracting states' but rather constitutes a new legal order capable of conferring rights and imposing obligations directly upon individuals. ${ }^{14}$

\footnotetext{
${ }^{10}$ For discussion, see e.g., P. Anderson, 'Ever Closer Union?', 43(1) London Review of Books (2021).

${ }^{11}$ Decision of the Court of Justice of the European Union of 10 June 2014 [2015] C 406/02. See e.g., F. Nicola, 'Waiting for the Barbarians: Inside the Archives of the European Court of Justice', in Kilpatrick and Scott, supra n. 9.

${ }^{12}$ At p. $1-2$.

${ }^{13}$ Horsley, supra n. 9.

${ }^{14} \mathrm{R}$. Plender, 'The European Court as an International Tribunal', 42(2) Cambridge Law Journal (1983) p. 279 at p. 279. See also Alter, supra n. 6, p. 27.
} 
Great Judgments takes on the challenge of divorcing Van Gend en Loos and Costa from 'wonderful' but equally 'unsatisfying' (p. 9) accounts of the transformation of the Treaty of Rome into an increasingly constitutionalised space within which individuals (as well as national courts) are direct actors. Phelan reinterprets these formative decisions as the story of a concerted judicial attempt to address a 'practical problem' in inter-state trade relations: recourse by states to unilateral self-help or retaliation measures in response to treaty infringements by other states (p. 9). For Phelan, three judgments of the Court of Justice - Van Gend en Loos, Costa and Dairy Products - were forged together to provide a unique and extraordinarily effective solution to that problem. This is not an entirely new perspective on the Court's formative case law. As his historical analysis expounds, early commentators, including Lecourt, also theorised the jurisprudence with reference to inter-state enforcement. ${ }^{15}$ But Phelan is correct in his claim that this particular strand of reasoning has become lost in mainstream accounts of the foundations of the (now) European legal order. ${ }^{16}$

\section{Revisiting 'Great Judgments'}

The book develops its primary argument over 10 chapters, preceded by a substantive introduction. The Introduction and final chapter (Chapter 10) frame the detailed analysis of the nine judgments that Phelan identifies as 'great' judgments to construct his revised narrative on inter-state relations: Pork Products (1961); Van Gend en Loos (1963); Costa v ENEL (1964); Dairy Products (1964); International Fruit (1972); ${ }^{17}$ Van Duyn (1974); ${ }^{18}$ Simmenthal (1978); ${ }^{19}$ Sheep Meat (1979) and Internationale Handelsgesellschaft (1970), ${ }^{20}$ respectively. Of the nine decisions, Van Gend en Loos, Costa v ENEL and Dairy Products take centre stage. Beyond the fact that they (for the most part) support his argument, Phelan does not expand further on why these judgments meet the test of a 'great'

\footnotetext{
${ }^{15}$ With reference to Costa, see e.g., Phelan's reference to N. Catalona, 'Portée des Traitrés Instituant les Communautés Européennes et Limites de Pouvoirs de Souverains des États Membres', 49 Le Doit et Les Affaires (1964) cited p. 78-79.

${ }^{16}$ The foundations of the now dominant 'constitutionalisation' narrative took hold quickly in early commentaries published in the late 60s onwards. See e.g., R-M Chevallier, 'Methods and Reasoning of the European Court of Justice in its Interpretation of Community Law', 2 Common Market Law Review (1965) p. 21, D.G Valentine, The Court of Justice of the European Communities (Stevens 1965) and A.W. Green, Political Integration by Jurisprudence (Sijthoff 1969).

${ }^{17}$ Joined Cases 21 to 24-72, International Fruit Company NV ECLI:EU:C:1972:115.

${ }^{18}$ ECJ 4 December 1974, Case 41/74, Van Duyn ECLI:EU:C:1974:133.

${ }^{19}$ ECJ 9 March 1978, Case 106/77, Amministrazione delle Finanze dello Stato v Simmenthal SpA ECLI:EU:C:1978:49.

${ }^{20}$ ECJ 17 December 1970, Case 11/70, Internationale Handelsgesellschaft ECLI:EU:C:1970:114.
} 
judgment of the Court (or explain what qualifies as a great judgment per se). That said, few would argue that, for one reason or another, many of the decisions discussed are anything other than significant milestones in the development of the European legal order.

Chapter 1, analysing Pork Products, sets the scene for Phelan's reorientation of the early case law around discussion of self-help and retaliation mechanisms in international trade law. The choice of that decision as an entry point is logical. It addressed the interpretation of Article 226 EEC, which empowered member states - through the Commission - to adopt protective measures to restrict trade in exceptional circumstances. As the first judgment on the Treaty of Rome, it also carries symbolic significance. The analysis of Pork Products foregrounds several points that frame discussion in subsequent chapters. These include, first, the fact that, in common with other international trade treaties, the Treaty of Rome included specific safeguard clauses to manage inter-state trade disputes. Second, that those clauses were distinctive by virtue of the fact that they required member states to seek prior authorisation from the European institutions to activate them lawfully. Third, that, in combination with its infringement procedures and provisions on the declaratory status of Court of Justice judgments, the Treaty of Rome provided an incomplete and, in his view, inadequate framework to address the practical problems of Treaty compliance between the member states.

Chapters 2, 3 and 4 do the heavy-lifting. It is across these three chapters that Phelan argues that, taken together, the Court's formative case law on direct effect and primacy ought to be understood as an unmistakable attempt by the Court of Justice to address gaps in the EEC Treaty's framework regulating inter-state trade retaliation measures. Van Gend en Loos, in particular, he argues, was not about recasting the relationship between the state and individuals in the European legal order. Instead, direct effect was established, he maintains, specifically to address the enforcement of trade obligations between the member states as contracting parties:

the central contribution of Van Gend en Loos is that it provided a mechanism that allowed the member states to give up the use of inter-state retaliation and reciprocity mechanisms to enforce European treaty obligations. ${ }^{21}$

The fact that this interpretation is nowhere to be found in the text of the judgment - which Phelan freely concedes (p. 51) - does not trouble the author. It is the deeper context that Phelan invites us to accept as the basis for this reconstruction of arguably the most significant decision of the Luxembourg Court. The Court's statements on the nature of the Treaty as the basis of a 'new legal

${ }^{21}$ At p. 53. 
order' that is expressly defined opposition to international law and defines the place of individuals within it as the bearers of direct rights and responsibilities are, in effect, reduced to distractions.

Chapters 3 and 4, respectively, connect Costa and Dairy Products with that central claim. In relation to Costa, the Court's assertion of the primacy of EEC Treaty norms is interpreted as reinforcing the introduction of direct effect as a means to foreclose the possibility for member states to resort to unilateral action to escape their treaty commitments or, equally, to respond to infringements by other member states. Here Phelan draws expressly on the text of the judgment, pointing to an explicit connection between his argument and the Court's statements on Article 226 EEC (on the adoption of protective measures). ${ }^{22}$ Dairy Products completes the picture. In that lesser-known decision, the Court of Justice was requested to rule on the legality of decisions by the Belgian and Luxembourg authorities to introduce new duties on the importation of certain dairy products. The Court ruled those decisions unlawful. As Phelan observes, in so doing, the Court of Justice explicitly rejected claims by both states that, under general principles of international law, they retained the right to take unilateral measures in response to alleged infringements of the EEC Treaty by other parties - in this case, the Commission. ${ }^{23}$

Chapter 4 on Dairy Products is absolutely integral to the analysis. It is really only in this chapter that Phelan elaborates on the comparative framework that he engages to develop his primary argument. Prior to this chapter, the reader has to make do with loose references to the world of 'international-style' self-help or retaliation mechanisms to contextualise discussion. ${ }^{24}$ Chapter 4 , therefore, adds welcome clarity on the specifics of the comparative framework. In particular, Phelan outlines the structure through which other international trade treaties typically address the practical problems of managing inter-state relations as well as the protections offered to states under general principles of international law. This context not only strengthens the comparative analysis, it also illuminates a central aspect of Phelan's overarching claim, namely that the Court of Justice's approach to filling gaps in the founding Treaty's provisions on enforcement was developed in opposition to the specific provisions of other contemporary trade agreements (notably, the GATT) and general principles of international law.

Throughout Great Judgments, Phelan positions his revised account of the case law on direct effect and primacy as a 'substitute' for international law mechanisms regulating inter-state trade relations. ${ }^{25}$ But, by substitute, it is clear that we are

\footnotetext{
${ }^{22}$ At p. 79.

${ }^{23}$ At p. 105.

${ }^{24}$ See esp. Chapters 1 and 2 analysing Pork Products and Van Gend en Loos, respectively.

${ }^{25}$ See e.g., pp. 51, 81, 83, 107 and 234.
} 
dealing with a contrasting regime: the Court's jurisprudence is interpreted as expressly excluding the availability of ordinary international trade provisions and accompanying 'fall-back' principles recognised in international law. This point is not concealed. ${ }^{26}$ But it does raise questions about the force of the underlying comparison. On the one hand, Great Judgments recasts the Treaty of Rome as an international trade agreement to expose a shared regulatory problem: the management of inter-state conflicts and, in particular, unilateral member state action. On the other hand, however, Phelan's revised interpretation of the Court's formative case law on direct effect and primacy invites us to accept that, functional parallels notwithstanding, the European legal order has adopted its own distinctive solutions that, in substance, juxtapose the Treaty of Rome with the default positions in international law.

Phelan's concluding chapter offers one way to square the circle. In Chapter 10, he defends the distinctive European solution, as fashioned by the Court of Justice in its landmark judgments, as a normative model to manage inter-state trade relations more generally. For Phelan, the European approach constitutes a 'remarkable trade policy achievement' (p. 228) that functions to promote a significant public good; specifically, 'the avoidance of retaliatory trade disputes, and the cluttering of market opportunities by unilateral safeguards in vitally important trade relationships' (p. 228). Developing this point further, Phelan also points in Chapter 7 (discussing Simmenthal) to other international trade treaties (specifically, NAFTA) that, in line with his rethinking of the Court of Justice's case law, have adopted mechanisms that similarly engage national courts as alternatives to traditional inter-state retaliation mechanisms. Annex 36A of the NAFTA Side Agreement on Environmental Protection (1993) is offered as a specific example. Rather oddly, he invokes that provision to reinforce his rewriting of the Court of Justice case law on direct effect. ${ }^{27}$ But the comparison is stronger in reverse - not least since that provision post-dates the judgments in Van Gend en Loos and Costa by 30 years.

\section{SUPPLEMENTARY ANALYSIS; SYNTHESISING NARRATIVES}

The remaining chapters of Great Judgments add further colour rather than force to the core argument developed in Chapters 3-4. Chapter 5 engages International Fruit to strengthen Phelan's recasting of Van Gend en Loos as a judgment regulating inter-state relations, rather than individual rights. Drawing inspiration from earlier attempts at similar exercises, he uses International Fruit to rewrite Van

\footnotetext{
${ }^{26}$ See e.g., pp. 3, 105, 224 and 225.

${ }^{27}$ At p. 182-183. North American Agreement on Environmental Cooperation (NAAEC) (1993) Can-Mex-US., 32 I.L.M. 1480, cited p. 182.
} 
Gend en Loos in a manner that brings out its concealed logic as the cornerstone of the European legal order's rejection of unilateral inter-state self-help and retaliation mechanisms. Chapters 6 and 7 attempt to relate Van Duyn and Simmenthal, respectively, to the revised account of direct effect and primacy developed in Chapters 3-5. Chapter 8, analysing Sheep Meat, reflects on the limits of the European legal order's framework on inter-state relations. Phelan uses this case to illustrate that reliance on direct effect and primacy does not guarantee state compliance with treaty obligations. At the same time, however, he also employs this decision to praise the relative strength of the European legal order's distinctive solution to the management of inter-state disputes in trade agreements - foregrounding his broader conclusions on that point in Chapter 10.

Chapter 9 stands out among the analysis of judgments in later chapters. In common with Chapters 5-8, that chapter supplements rather than constitutes the core argument. But more so than the chapters it follows, it provides greater insights into the relationship between Phelan's argument and the established narratives on judicial empowerment and individual rights that Great Judgments challenges its readers to rethink.

Phelan's focus in Chapter 9 is on Internationale Handelsgesellschaft - the judgment in which, as is well-known, the Court of Justice famously asserted its exclusive competence to adjudicate on the constitutionality of EU Acts that were alleged to infringe fundamental rights as protected under the constitutions of the member states. Phelan acknowledges that this decision does not fit neatly with the book's otherwise coherent focus on rethinking landmark judgments through the prism of inter-state trade relations:

the question of how individuals are to be protected from violations of fundamental rights arising from treaty obligations is not very directly connected with the challenges of enforcement and escape in international trade politics. ${ }^{28}$

To integrate Internationale Handelsgesellschaft into his core argument, Phelan adjusts his comparative framework. That decision, he argues, should not be rationalised with reference to inter-state rules on self-help and retaliation measures. Rather, it ought to be viewed alongside contemporary judgments of national constitutional courts - notably those of the Italian and German constitutional courts - interpreting international treaty obligations in light of national constitutional rights:

A more appropriate context to understand the challenge faced by the Court of Justice in Internationale Handelsgesellschaft is the wider group of cases where

${ }^{28}$ At p. 214. 
national constitutional courts ... were called upon to review whether treaty obligations violated fundamental rights protected by their national constitutions. This wider group of cases involves, above all, treaties other than the European treaties. ${ }^{29}$

Phelan relies on this adjustment to his comparative framework to assert that Internationale Handelsgesellschaft was principally concerned with the primacy of Union law in connection with inter-state trade relations, not the development of the Court of Justice's role in protecting fundamental rights. This dilution of the familiar understanding of Internationale Handelsgesellschaft as a cornerstone of the EU's fundamental rights framework helps to bring that decision within the book's core argument. But it is also somewhat strained, not least as Phelan is forced to concede that Internationale Handelsgesellschaft has subsequently acquired the significance that his analysis attempts to deconstruct - at least in its contemporary historical context. ${ }^{30}$

More fundamentally, however, the shift in comparative perspective effected in Chapter 9 provides an insight into the relationship between Phelan's core argument and the dominant narrative that he considers 'unsatisfying'. It is in this chapter that the reader first gets the sense that Phelan's appeal to 'rethink' the Luxembourg Court's formative rulings on direct effect and primacy actually involves modifying rather than repudiating established interpretations of Van Gend en Loos and Costa. To rationalise Internationale Handelsgesellschaft with his core argument, Phelan ends up implicitly endorsing an understanding of the Court of Justice as a proto-constitutional court that exercises functions parallel to those of its domestic counterparts. That view of the EU Court, of course, underpins the vision of the 'constitutionalised' European legal order that his rethinking of Van Gend en Loos and Costa in Chapters 2 and 3, respectively, explicitly problematises.

As Chapter 9 signals, Great Judgments ultimately ends up synthesising rather than repudiating narratives. Chapter 10 provides further clarity on that point. Here Phelan gestures more explicitly towards the defence of a more nuanced relationship between his core thesis and the dominant account of the Court of Justice's formative case law on, in particular, direct effect and primacy. ${ }^{31}$ In the concluding analysis, Phelan defends, 'understanding the direct-effect doctrine both as a very specific instrument of inter-state trade politics and as the potential basis for a constitutional understanding of the Treaty of Rome'. ${ }^{32}$ Of the two narratives, Phelan leaves no doubt as to the priority he attaches to the former.

\footnotetext{
${ }^{29}$ At p. 215.

${ }^{30}$ At p. 219.

${ }^{31}$ See p. 237.

${ }^{32}$ At p. 237.
} 
But prioritisation remains the watchword: Great Judgments remains open to recognising the significance that Van Gend en Loos and Costa assumed in relation the judicial transformation of the Community legal order. That is an important clarification that could also have been brought out more clearly earlier in the analysis.

A final point of critique in relation to the core argument addresses the book's structure. Phelan is correct to claim that Great Judgments is a monograph rather than a casebook. However, adopting a judgment-by-judgment approach to the analysis of the Court's output, much of the book does read like a series of extended case commentaries - not unlike Maduro and Azoulai's, The Past and Future of EU Law: Revisiting the Classics on the 50 Anniversary of the Rome Treaty. ${ }^{33}$ This is also the result of the uniform structure the book imposes across Chapters 2-9. Each chapter begins with a review of the Advocate General's Opinion, followed by a summary of the Court's decision. Phelan then expands discussion with reference to 'related cases' before progressing to offer 'analysis and context' which includes a review of existing scholarly perspectives. Only after progressing through this matrix does the reader reach Phelan's original analysis his 'rethinking' of the landmark judgments. In certain chapters, that analysis is also remarkably short. ${ }^{34} \mathrm{~A}$ more thematic approach would have certainly enhanced the quality of the primary argument. It would also have provided a framework to clarify some key baselines much earlier in the book - notably, the comparative framework on international self-help and retaliation measures.

\section{LECOURT, LECOURT, LECOURT!}

Great Judgments advances a second claim in relation to the Court's formative jurisprudence on the foundations of the European legal order. Phelan argues that the Court of Justice's establishment of direct effect and primacy to displace traditional inter-state self-help and retaliation mechanisms in comparable trade treaties owes a significant part of its existence to the 'personal judicial philosophy' (p. 7) of one individual: Robert Lecourt. This is a bold claim, particularly given the available documentary evidence. The French lawyer published no memoirs of his time at the Court (including as its President). He also, Phelan informs us, appears to have ordered his personal papers be destroyed prior to his death. ${ }^{35}$ Added to this, the institutional context within which the early Court operated (and continues to operate) makes the task of attributing jurisprudential developments to individuals a difficult one. The 'great judgments' upon which Phelan's primary argument is

\footnotetext{
${ }^{33}$ L. Azoulai and M. Poiares Maduo (eds.), The Past and Future of EU Law: Revisiting the Classics on the $50^{\text {th }}$ Anniversary of the Rome Treaty (Hart Publishing 2010).

${ }^{34}$ Running to just three pages in Chapter 7 , for example.

${ }^{35}$ At p. 6.
} 
based are single judgments of the Court agreed jointly by all its members following deliberations that remain secret.

Lecourt's writings are referenced unevenly across the chapters, but the thrust of the argument is clear. Phelan submits that Lecourt,

brought to the Court of Justice ... a profound rejection of any form of self-help in law enforcement as well as an openness to ambitious developments of the law by courts themselves. ${ }^{36}$

This conclusion is extrapolated, principally, from the French lawyer's doctoral thesis on the suppression of self-help remedies within the French legal system as well as his much later writings on European law. ${ }^{37}$ It also builds on Phelan's early scholarship. ${ }^{38}$ More broadly, it connects with the work of European legal historians whose research has so brilliantly illuminated the significant contribution of a number of prominent members of the Court of Justice - including Lecourt to the initial development of the Community legal order. ${ }^{39}$

There is no doubt that Lecourt played an important role in the Court's formative years, not least in his role as Court President. Nonetheless, in claiming that 'no other single judge had such a profound impact' (p. 5) Phelan appears to hear his voice louder than the rest of us do. Yes, there is evidence that does connect Lecourt to the modified narrative that Grand Judgment advances as its primary argument. In Chapter 3, for example, Phelan draws connections between his reinterpretation of the judgments in Van Gend en Loos, Costa and Dairy Products as judicial efforts to manage inter-state conflicts with Lecourt's writings on the primacy doctrine in his 1976 book, L'Europe des juges. However, reading Great Judgments leaves one with a far stronger impression that it was a much broader range of individuals whose collective efforts may be invoked to support the book's core argument. This, of course, aligns with the work of Rasmussen, Boerger, Davies and other leading legal historians.

In the end, whether or not Lecourt qualifies as the Luxembourg Court's most influential figure during its formative period is not that important, not least in

\footnotetext{
${ }^{36}$ At p. 7.

${ }^{37}$ See e.g., R. Lecourt, L'Europe des juges (Bruylant 1976) and R. Lecourt, 'Quel eut été le doit de Communautés sans les arrêts de 1963 et 1964 ?', in Mélanges Jean Boulouis : l'Europe et le droit (Dalloz 1991).

${ }^{38}$ E.g., W. Phelan, 'The Revolutionary Doctrines of European Law and the Legal Philosophy of Robert Lecourt', 28(3) European Journal of International Law (2017) p. 935.

${ }^{39}$ E.g., A. Boerger and M. Rasmussen, 'The Making of European Law: Exploring the Life and Work of Michel Gaudet', 57 American Journal of Legal History (2017) p. 51 and V. Fritz, Juges et avocats généraux de la Cour de l'Union européenne (1952-1972): une approache biographique de l'histoire d'une révolution juridique (Klostermann 2018).
} 
relation to Phelan's primary argument. In combination with the comparative analysis of other international trade treaties, Phelan's excursus into extra-judicial materials provides the deeper context that elevates Grand Judgments as work of legal scholarship. What is unquestionable - and widely recognised - is that the Court of Justice's landmark judgments on the foundations of the European legal order were the product of a period of extraordinary creative energy that was to define the process of European integration. Judges at the Court - including Lecourt - were the source of that energy, alongside a broader network that, as Phelan's study details throughout, also engaged national courts and legal academics.

\section{CONCLUDing REMARKS}

Great Judgments is a stimulating read. In attempting to rethink the most entrenched of all European legal narratives, Phelan is engaged in something ambitious and refreshing. His approach, whilst coming unstuck in places, breaks with the now dominant conceptualisation of the $\mathrm{EU}$ as a constitutionalised legal space. The significance that Phelan attaches to Lecourt as the European legal order's most influential judge is difficult to sustain and, at time, rather distracting. His primary argument, however, is more compelling. Phelan presents a strong case - drawing on his fusion of doctrine and deeper context - that the Court's formative judgments on, in particular, direct effect and primacy may indeed be reconstructed as he wishes us to see them, namely as a judicial response to the practical problems of managing inter-state trade relations. Ultimately, this 'rethinking' of the case law which, in part, aligns with the views of some early commentators - enriches rather than displaces the dominant account that, as is well-documented, views decisions such as Van Gend en Loos and Costa as steps towards the 'constitutionalisation' of the European legal order.

The conclusion that we ought to rethink our interpretation of some of the Court of Justice's most significant judgments to that effect is, however, not pushed very far. What is missing, regrettably, is a much deeper sense of the relationship between his modified reading of the Court's early jurisprudence and the broader legal and political landscape of European integration - both contemporaneously and as this has subsequently developed. But Phelan does leave his readers with something important: a clear view on the place of individuals (and national courts) under the EEC Treaty that contrasts strikingly with the familiar narrative that reads the former as the bearers of direct rights (including fundamental rights) and the latter as newly empowered 'Community courts'. The vision of direct effect and primacy principally as inter-state mechanisms advances a much more communitarian conceptualisation of European citizenship. Rather than emphasising the place of individuals (and the protection of individual rights) within the EU 
legal order, this modified view acknowledges, as a shared public good, the significant collective contribution that private litigants made to ensuring state compliance with the Treaty of Rome. As Great Judgments asserts, this ought to feature more prominently in analyses of the Court's formative case law on direct effect and primacy.

At the same time, however, there is something all too familiar about Phelan's book. Its conceptual framework and primary argument notwithstanding, Great Judgments shares much in common with the legal scholarship that it critiques as 'unsatisfying'. In the end, it simply explains the Court's formative case law on the foundations of the European legal order in well-known terms. It describes the Court of Justice that, with little sense of textual fidelity, acted decisively early on to fill gaps in the Treaty framework to transformative effect. Phelan does not challenge (or problematise) that story. Great Judgments just asks us to take a modified view of the underlying functional purpose that prompted the Court's judicial creativity in the hands of a body of influential individuals, including Lecourt. It is unsurprising, therefore, that this new addition to the scholarship on the Luxembourg Court has been so positively received by leading proponents of the dominant 'constitutionalisation' narrative. ${ }^{40}$ In common with the literature it purports to critique, Great Judgments ultimately performs for EU scholars an analogous function to that which Livy's History of Rome discharged for Roman citizens: it sustains rather than problematises sociological foundations. The Court's early case law on direct effect and primacy as the basis of the European legal order is rethought, but certainly not challenged.

${ }^{40}$ See e.g., J.H.H. Weiler at $\langle$ https://www.ejiltalk.org/10-good-reads-part-2/〉, visited 23 August 2021. 